\title{
Cocarbonization of Low Sulfur Vacuum Residue and FCC Decant Oil Aided by Additive Pitch of High Aromaticity
}

\author{
Yasuhiro Nesumi $^{\dagger 1}$, Akemi Azuma ${ }^{\dagger 1)}$, Takashi Oyama ${ }^{\dagger 1)}$, Yoshio Todo ${ }^{\dagger 1)}$, \\ Isao MOCHIDA $^{\dagger 2) *}$, and Yozo KoraI ${ }^{\dagger 2)}$ \\ †1) Marifu Refinery, KOA Oil Co., Ltd., 6-1-1 Waki, Waki-cho, Kuga-gun, Yamaguchi 740 \\ †2) Institute of Advanced Material Study, Kyushu University, 6-1 Kasuga Koen, Kasuga, Fukuoka 816
}

(Received October 24, 1989)

\begin{abstract}
Cocarbonization of a low sulfur vacuum residue (LSVR) and a fluid catalytic cracking decant oil (FCC-DO) with the aid of Ashland A-240 pitch was studied, using tube bomb reactor at a temperature range of $460-480^{\circ} \mathrm{C}$, under pressure of $8 \mathrm{~kg} / \mathrm{cm}^{2}$, to eliminate bottom mosaic-coke which was formed in the process with the given particular LSVR and FCC-DO. Addition of A-240 was highly effective to reduce the mosaic-coke, 30 and $5 \%$ added being found to eliminate completely at 480 and $460^{\circ} \mathrm{C}$, respectively. The bottom mosaic-coke formed by LSVR alone was removed with less amount of A-240. Addition of A-240 tended to increase coefficient of thermal expansion(CTE) of the resultant lump coke at the optimum temperature, as compared to that obtained without A-240. The formation mechanism of bottom mosaic-coke is presumed to be that the heaviest asphaltene of high reactivity in the LSVR is carbonized into QI spheres of low solubility, in the somewhat paraffinic matrix, because of insufficient aromaticity of the FCC-DO, at the early stage of the carbonization. Spheres formed under such circumstances precipitate to the bottom without any growth or coalescence, forming the mosaic-coke. Higher aromaticity of the matrix mediates such QI to carbonize together, allowing formation of homogeneous texture in the whole area of resultant coke. Influence of carbonization temperature on CTE is briefly discussed in relation to their reactivity of blended feedstocks, based on the mechanism leading to production of needle coke.
\end{abstract}

\section{Introduction}

Better quality needle coke having low coefficient of thermal expansion (CTE) and stable quality is most sought for in the modern coking technology. Cocarbonization of petroleum vacuum residue (VR) and fluidized catalytic cracking decant oil(FCC-DO) has been recognized to produce needle coke of excellent flow texture and low $\mathrm{CTE}^{1)}$. However such cocarbonization of some combination of feeds tends to produce unwanted mosaic-coke having high CTE at the bottom of the coker drum ${ }^{2) \sim 4)}$.

The present authors reported that the carbonization in the tube bomb well simulates that of the several feedstocks from both coal and petroleum in the commercial coker, reproducing $\mathrm{CTE}^{5), 6)}$. Hence, using the bomb, the carbonization mechanism, leading to formation of needle coke, has been pursued in details?).

In the present study, cocarbonization of particular low sulfur vacuum residue(LSVR) and FCC-DO in the presence of highly aromatic pitch, A-240,

* To whom correspondence should be addressed. was examined to eliminate the bottom mosaic texture in the resultant coke. CTE of the coke was also measured to get information on applicability of such cocarbonization to commercial operation. The mechanism of formation and elimination of bottom mosaic is briefly discussed. Such a study may also provide clues to solve problems in the shot coke formation which also causes serious troubles in the coker operation ${ }^{8)}$.

\section{Experimental}

A LSVR, a FCC-DO, and Ashland A-240 pitch were used in as received forms. The analytical data, therefore, are summarized in Table 1. After thorough mixing at $c a .80^{\circ} \mathrm{C}$, blended sample of $40 \mathrm{~g}$ was wrapped with aluminum foil $(150 \mathrm{~mm}$ height, $20 \mathrm{~mm}$ diameter) and carbonized in a stainless steel tube-bomb. Carbonization temperature, pressure, and heating rate were 460 or $480^{\circ} \mathrm{C}$, $8 \mathrm{~kg} / \mathrm{cm}^{2}$, and $250^{\circ} \mathrm{C} / \mathrm{min}$, respectively. After the carbonization, the lump coke was recovered from the tube and examined for anisotropic texture, under a reflected light microscope, at both middle and bottom areas on its perpendicular section (magnification, $\times 50)$. CTE(coefficient of thermal 
Table 1 Feedstock Properties

\begin{tabular}{|c|c|c|c|c|c|c|c|c|c|}
\hline & \multirow[b]{2}{*}{ C } & \multicolumn{2}{|c|}{ Micro analyses [\%] } & \multicolumn{3}{|c|}{ Atomic ratio } & \multicolumn{3}{|c|}{ Solubility [\%] } \\
\hline & & $\mathrm{H}$ & $\mathrm{N}$ & $S$ & $\mathrm{C} / \mathrm{H}$ & $f a^{1)}$ & HS & HI-BS & BI \\
\hline $\mathrm{LSVR}^{2)}$ & 86.2 & 12.5 & 0.4 & 0.2 & 0.6 & 0.18 & 92 & 8 & 0 \\
\hline FCC-DO $\left.{ }^{3}\right)$ & 88.9 & 9.5 & 0.1 & 0.4 & 0.8 & 0.54 & 100 & 0 & 0 \\
\hline $\mathrm{A}-240^{4)}$ & 91.5 & 5.6 & 0.1 & 一 & 1.4 & 0.88 & - & 94.5(BS) & 5.5 \\
\hline
\end{tabular}

1) Aromaticity, 2) A petroleum vacuum residue of low sulfur content, 3) A FCC decant oil, 4) Ashland A-240 pitch

expansion) of the lump coke was also measured (temperature ranged from room temperature to $500^{\circ} \mathrm{C}$ ) a fter calcination at $1,000^{\circ} \mathrm{C}$.

Intermediates of carbonization were also examined for their anisotropic development and solubility in benzene, THF, and quinoline. The benzene soluble substances were analyzed with $400 \mathrm{MHz}$ FT-NMR.

Experimental details were described in previous papers $^{5), 6)}$.

\section{Results}

\subsection{Optical Texture of Cocarbonized Coke}

Montage micrographs of lump cokes produced through the cocarbonization at 480 and $460^{\circ} \mathrm{C}$ are illustrated in Figs. 1 and 2, respectively, where the mixing ratio of FCC-DO and LSVR was fixed at unity and A-240 was added up to $30 \%$. The thickness of bottom mosaic areas is summarized in Table 2.

In cocarbonization of LSVR and FCG-DO at $480^{\circ} \mathrm{C}$, thin mosaic texture was formed at the bottom of resultant lump coke, while excellent uni-axially oriented flow texture was developed at the middle of the lump as shown in Fig. 1-A. Addition of A-240 was effective to reduce the formation of bottom mosaic at this temperature, and its addition of up to $30 \%$ eliminated the bottom mosaic texture completely, as shown in Fig. 1-B to $\mathbf{D}$ and summarized in Table 2. Unfortunately, flow texture of the middle portion became less oriented as addition of A-240 was increased.

At carbonization temperature of $460^{\circ} \mathrm{C}$, the thickness of bottom mosaic texture in the carbonization of LSVR and FCC-DO increased as illustrated in Fig. 2-A. The thickness of the bottom mosaic area, however, was decreased more effectively by the addition of A-240, such that the mosaic texture disappeared completely by addition of $5 \%$, as shown in Fig. 2-B. The orientation of flow texture at the middle portion in the coke

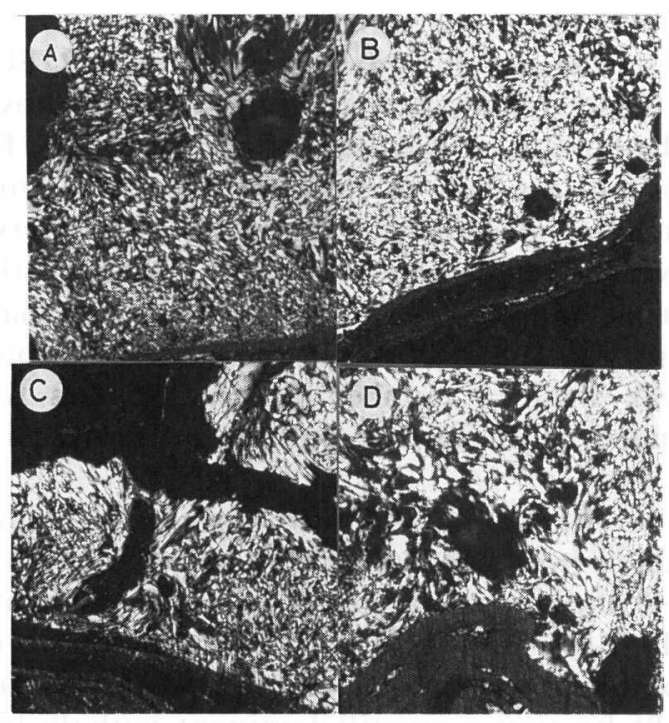

$\overleftrightarrow{400 \mu \mathrm{m}}$

Amount of A-240: (A) 0\%, (B) 5\%, (C) 10\%, (D) $30 \%$

Fig. 1 The Optical Microphotographs of Bottom Coke Produced from VR and FCC-DO (50/50) by the Addition of $\mathrm{A}-240$ at $480^{\circ} \mathrm{C}$

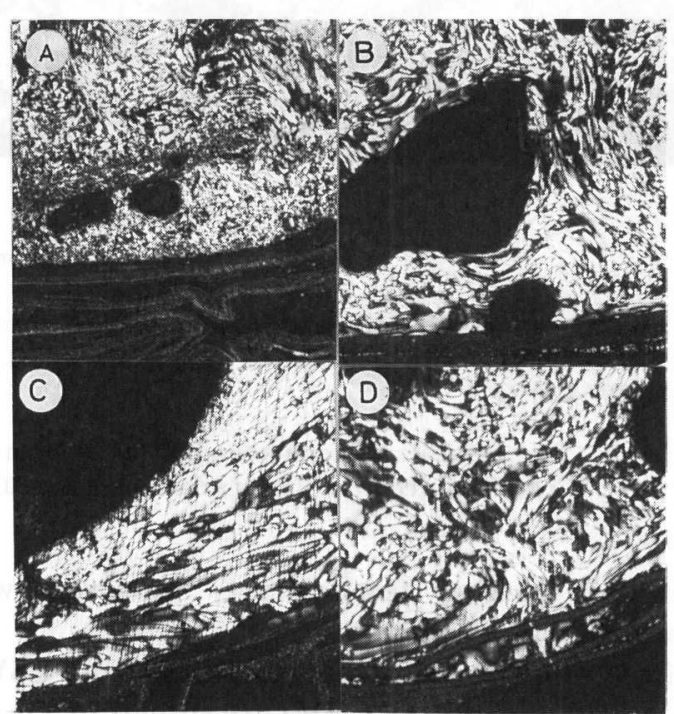

L00 $\mathrm{mm}$

Amount of A-240: (A) $0 \%$. (B) $5 \%$, (C) $10 \%$, (D) $30 \%$

Fig. 2 The Optical Microphotographs of Bottom Coke Produced from VR and FCC-DO $(50 / 50)$ at $460^{\circ} \mathrm{C}$ by the Addition of A-240 
Table 2 Thickness of Bottom Mosaic Texture and CTE Values of Lump Coke

\begin{tabular}{|c|c|c|c|c|}
\hline \multirow[t]{3}{*}{ Feed composition } & \multicolumn{4}{|c|}{ Carbonization temp. } \\
\hline & \multicolumn{2}{|c|}{$460^{\circ} \mathrm{C}$} & \multicolumn{2}{|c|}{$480^{\circ} \mathrm{C}$} \\
\hline & T.B. $\mathrm{M}^{1)}$ & CTE $^{2)}$ & T.B.M ${ }^{1)}$ & CTE $^{2)}$ \\
\hline $\mathrm{VR} / \mathrm{DO}=50 / 50$ & 2.3 & 0.36 & 1.1 & 0.23 \\
\hline \multicolumn{5}{|l|}{$\mathrm{VR} / \mathrm{DO} / \mathrm{A}-240$} \\
\hline$=50 / 50 / 5$ & 0 & 1.30 & 1.2 & - \\
\hline $50 / 50 / 10$ & 0 & - & 0.8 & - \\
\hline $50 / 50 / 30$ & 0 & - & 0 & 0.97 \\
\hline $\mathrm{VR}=100$ & 3.0 & 1.20 & 1.1 & 1.30 \\
\hline \multicolumn{5}{|l|}{$\mathrm{VR} / \mathrm{A}-240$} \\
\hline$=100 / 10$ & 0 & 1.48 & 0 & 0.76 \\
\hline $100 / 30$ & 0 & - & 0 & - \\
\hline
\end{tabular}

1) Thickness of bottom mosaic texture $[\mathrm{mm}]$

2) Coefficient of thermal expansion $\left[\times 10^{-6} /{ }^{\circ} \mathrm{C}\right]$

Middle portion of coke lumps free from the bottom mosaic was measured.

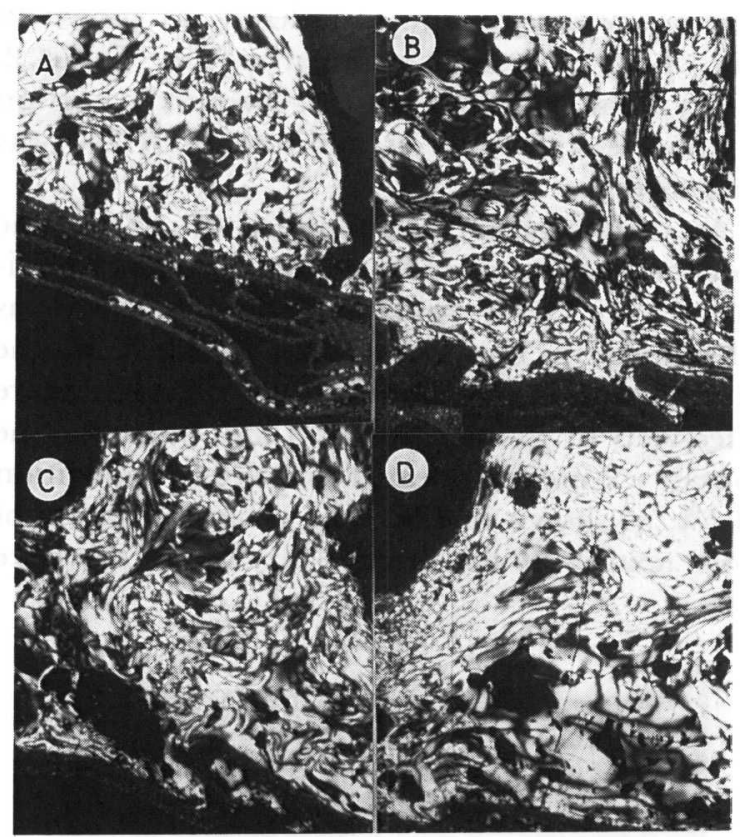

${ }_{400 \mu \mathrm{m}}$

Amount of A-240 and carbonization temperature: (A) $0 \%-480^{\circ} \mathrm{C}, \quad$ (B) $30 \%-480^{\circ} \mathrm{C}, \quad$ (C) $10 \%-460^{\circ} \mathrm{C}$, (D) $30 \%-460^{\circ} \mathrm{C}$

Fig. 3 The Optical Microphotographs of Bottom Coke Produced from VR by Addition of A-240

produced at this temperature, however, was disturbed by the addition.

Microphotographs of coke produced from LSVR and A-240 without FCC-DO are shown in Fig. 3. LSVR alone formed bottom mosaic texture, which was very thick as previously reported ${ }^{9)}$. Addition of $\mathrm{A}-240$ was very effective to eliminate bottom mosaic formed in the coke from LSVR alone. Addition of $10 \%$ was enough to eliminate the bottom mosaic texture completely at both carboni- zation temperatures of 460 and $480{ }^{\circ} \mathrm{C}$. The uniaxial orientation of flow texture at the middle portion, however, was certainly inferior, as compared to that of the coke from the blends of LSVR and FCC-DO.

\subsection{CTE Range of Lump Coke}

The CTE range of middle portions of coke lumps produced from blends of LSVR, FCC-DO and A-240 is summarized in Table 2. LSVR alone provided coke lumps of high CTE (1.20 and $\left.1.30 \times 10^{-6}{ }^{\circ} \mathrm{C}^{-1}\right)$ at carbonization temperatures of 460 and $480^{\circ} \mathrm{C}$, respectively. Its cocarbonization with FCC-DO (blending ratio 1:1) was very effective to decrease CTE to 0.36 and $0.23 \times 10^{-6}{ }^{\circ} \mathrm{C}^{-1}$ at 460 and $480^{\circ} \mathrm{C}$, respectively, as reported previously, measured of coke free from bottom mosaic formation ${ }^{3)}$,4).

Addition of A-240 to the LSVR/FCC-DO blend (1:1) by 5 and $30 \%$, increased significantly the CTE values to 1.3 and $0.97 \times 10^{-6}{ }^{\circ} \mathrm{C}^{-1}$ at 460 and $480^{\circ} \mathrm{C}$, respectively. Addition of $\mathrm{A}-240$ to $\mathrm{LSVR}$ alone by $10 \%$ decreased CTE to $0.76 \times 10^{-6}{ }^{\circ} \mathrm{C}^{-1}$ at $480^{\circ} \mathrm{C}$, while increased to $1.48 \times 10^{-6}{ }^{\circ} \mathrm{C}^{-1}$ at $460^{\circ} \mathrm{C}$. Thus, addition of $\mathrm{A}-240$ tended to increase the CTE when optimum carbonization temperature was selected for the strictly LSVR/FCC-DO blend. A higher temperature could improve CTE significantly as may be expected from the mechanism assumed previously7),10).

\subsection{Carbonization Intermediates}

The microphotographs of carbonized products from LSVR/FCC-DO $(1: 1)$ and its blend with A-240 $(30 \%)$ at $480^{\circ} \mathrm{C}, 1 \mathrm{~h}$ after the carbonization had started, are illustrated in Fig. 4. LSVR/FCGDO blend already showed the formation of mosaic in the bottom, at this stage of carbonization (Fig. 4-B), while a belt of flow texture and a small number of mesophase spheres could be observed above the mosaic-texture zone. In a marked contrast, not mosaic, but excellent flow domaintexture was found at the bottom by the addition of A-240, while a number of large spheres were scattered in the middle portion as illustrated in Fig. 4-A.

The change of solubility in the carbonized products from LSVR/FCC-DO and its blend with A-240 until their final solidification, are illustrated in Fig. 5. LSVR/FCC-DO formed quinoline insoluble product after $30 \mathrm{~min}$, while $\mathrm{HS}$ and HI-BS fractions were still dominant, with the least amount of BI-QS. Longer time for carbonization increased $\mathrm{BI}-\mathrm{QS}$, as well as $\mathrm{QI}$, decreasing rapidly the HI-BS and gradually the HS. The solidification took place $2.0-2.5 \mathrm{~h}$ after the carbonization started while the QI content increased from 30 to $95 \%$. HS, which occupied $30 \%$ in the product after 


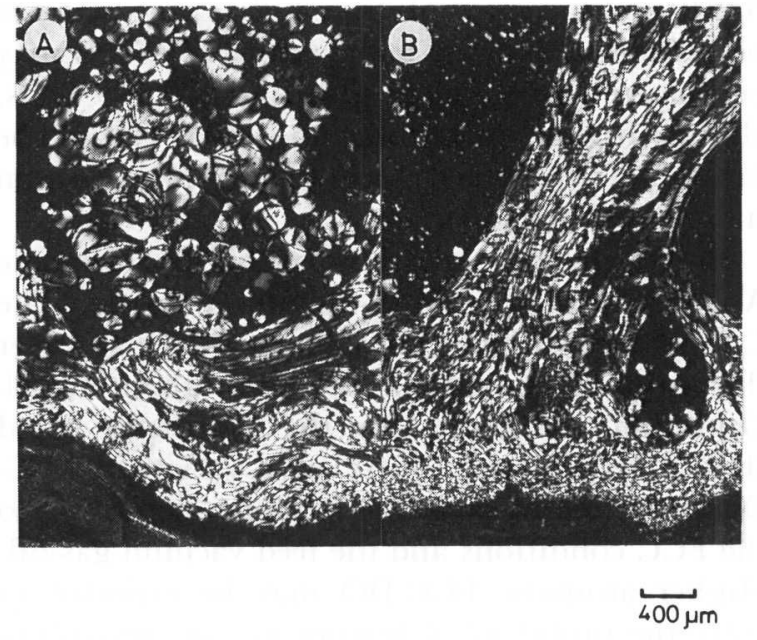

Carbonization temperature and time: $480^{\circ} \mathrm{C}$ and $1 \mathrm{~h}$ (A) with A-240(30\%), (B) without

Fig. 4 The Optical Microphotographs of Carbonization Intermediates from VR and FCC-DO with and without A-240
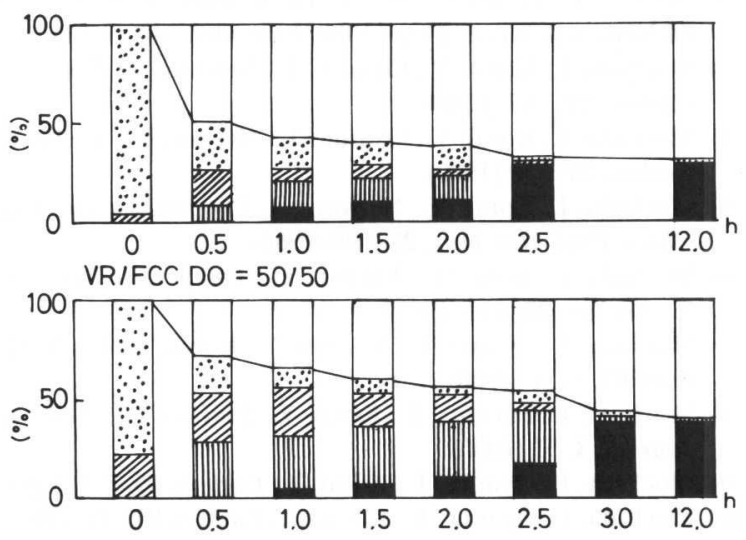

VR/FCC DOIA $240=50 / 50 / 30$

Carbonization temperature: $480^{\circ} \mathrm{C}$

QI, $\mathrm{HI}-\mathrm{BS}, \mathrm{m}$ BI-QS, $\mathrm{BS}$

Fig. 5 Variation in Solubilities of Carbonization Intermediates

$2 \mathrm{~h}$, disappeared almost completely at this solidification stage.

Addition of A-240 increased siginificantly the content of BI-QS from the early stage $(0.5 \mathrm{~h})$ of carbonization. QI was already formed at this stage. HS decreased somewhat rapidly, while HI-BS did gradually. QI increased steadily while BI-QS remained almost unchanged until $2.5 \mathrm{~h}$, just before the solidification. The solidification took place between 2.5 to $3.0 \mathrm{~h}$ after the carbonization started, while the QI content increased from 50 to $95 \%$. It should be noted that HS content of $15 \%$ in the product disappeared at this stage and that major QS content of $50 \%$ in the product was transformed to QI.

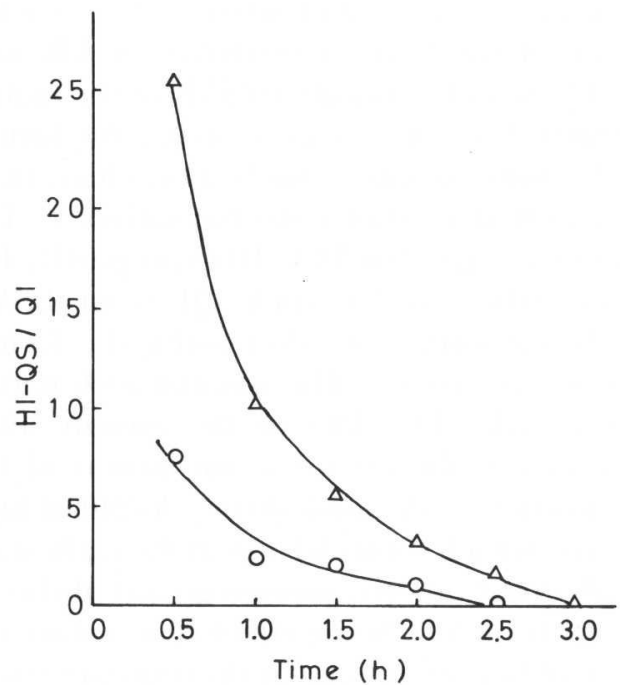

$\triangle \triangle: V R / F C C-D O / A-240=50 / 50 / 30$ అӨ: VR/FCC-DO $=50 / 50$

Fig. $6 \mathrm{HI}-\mathrm{QS} / \mathrm{QI}$ Ratios vs. Carbonization Time at $480^{\circ} \mathrm{C}$

The transition of $\mathrm{HI}-\mathrm{QS} / \mathrm{QI}$ ratio in the carbonized products is summarized in Fig. 6. It is certainly definite that greater amount of HI-QS relative to QI was present in LSVR/FCC-DO/A-240 blend from the initial stage of carbonization until the solidification.

\section{Discussion}

The present authors have established the mechanism of needle coke production as consisting of two major steps, namely, the formation of bulk mesophase and uni-axial arrangement of its planar molecules by gas evolution at its solidification ${ }^{7), 10)}$. The mesophase is formed through the nucleation, growth and coalescence of anisotropic spheres in the proper matrix ${ }^{11)}{ }^{14)}$. Such steps are strongly influenced by the carbonization feedstock and conditions, both of which define the solubility, fusibility and reactivity of the intermediates during the carbonization. The CTE of the coke is essentially determined by the degree of uni-axial orientation of constituent planar molecules ${ }^{9)}$ which is governed by the viscosity change of the mesophase and the amount of gas evolution at its solidification stage $\mathrm{f}^{7}$. The cocarbonization of FCC-DO and LSVR provided more favorable CTE of resultant coke through the mechanism discussed $^{4)}$ above.

The bottom mosaic texture was formed at an early stage of the carbonization when the mesophase spheres produced from the heaviest portion of the feedstock precipitated to the bottom of the tube without significant growth and coalescence because of their low solubility in the 
paraffinic matrix and high viscosity. The heaviest asphaltene of the highest reactivity in VR may produce QI, which is hardly soluble in the matrix yet aromatized at early stage, causing the formation of bottom mosaic. Such a mechanism is common to that of shot coke formation ${ }^{8)}$. The blending of the present FCC-DO can partly, but not completely dissolve such QI from LSVR during the carbonization, decreasing the formation of bottom mosaic. The paraffin-rich nature of the particular FCC-DO in the present study causes it to fail the complete mediation of the heaviest portion of the asphaltene. A-240 of high aromaticity, which forms BI-QS at the early stage of the carbonization, may possess greater ability to dissolve QI from VR, being effective to reduce the formation of bottom mosaic in the resultant coke. Paraffins in FCC-DO retard the dissolution of QI, thereby requiring higher aromatic solvent in the cocarbonization of LSVR and FCC-DO than in case of single carbonization of LSVR.

Such a mechanism for the formation of bottom mosaic suggests strong influence on the carbonization conditions. Higher carbonization temperature enhances the dissolution of QI, namely, cracking of paraffins and alkyl aromatics to enhance the aromaticity of matrix, as well as the carbonization of QI to lower solubility. Hence, delicate balance of increasing the aromaticity and QI defines the amount of the bottom mosaic-coke, according to the properties of carbonizing substances. In a particular case of the present study, higher temperature of $480^{\circ} \mathrm{C}$ tended to require more A-240 for complete eliminations of bottom mosaiccoke.

Addition of A-240 solved the problem of bottom mosaic-coke, even though it increased CTE of the coke. Since the CTE is strongly influenced by the carbonization temperature, and higher temperature is expected to provide lower CTE for coke produced from the blend of LSVR/FCC-DO/A-240 with stabilized reactivity through efficient cocarbonization. At $480^{\circ} \mathrm{C}$, the solidification in the carbonization is delayed greatly by the addition of
A-240 and the gas evolution at that time may not be sufficient. Lower temperature of $460^{\circ} \mathrm{C}$ may emphasize this trend to give high CTE. Thus, slightly higher temperature above $480^{\circ} \mathrm{C}$ could be favorable, while the chances to form more bottom mosaic coke may increase.

In conclusion, addition of highly aromatic A-240 solved the problem of bottom mosaic. The CTE of the resultant coke increased slightly under the optimum conditions obtained without A-240. Optimum conditions for the particular blend should be explored. There are a variety of FCCDO produced in Japanese refineries according to the FCC conditions and the feed vacuum gas-oil. Higher aromatic FCC-DO may be expected to solve the problems of bottom mosaic, providing favorable CTE at the same time ${ }^{15)}$.

\section{References}

1) Stocks, C. A., Guercio, V. J., Edol \& Kohle, Erdgas Petrochemi, 38, 31 (1985).

2) Romers, E., Menerdez, Marsh, H., Reinoso, F. R., Carbon 88 Newcastle upon Tyne, 1988, Extended Abstr., 256.

3) Mochida, I., Korai, Y., Oyama, T., Nesumi, Y., Todo, Y., Carbon, 27, 367 (1989).

4) Mochida, I., Korai, Y., Oyama, T., Nesumi, Y., Todo, Y., Carbon, 27, 359 (1989).

5) Mochida, I., Korai, Y., Nesumi, Y., Oyama, T., Ind. Eng. Chem. Prod. Res. Dev., 25, 198 (1986).

6) Mochida, I., Korai, Y., Fujitsu, H., Oyama, T., Nesumi, Y., Carbon, 25, 259 (1987).

7) Mochida, I., Oyama, T., Nesumi, Y., Korai, Y., Fei, Y. Q., Fuel, 67, 1171 (1988).

8) Mochida, I., Furuno, T., Korai, Y., Fujitsu, T., Oil \& Gas Journal, 3, 51 (1986).

9) Mochida, I., Oyama, T., Korai, Y., Carbon, 25, 273 (1987).

10) Mochida, I., Oyama, T., Korai, Y., Carbon, 26, 26 (1988).

11) Brooks, J. D., Taylor, G. H., "Chemistry and Physics of Carbon”, ed. by Walker, P. L. Jr., Marcel Dekker, Inc., New York (1964), Vol. 4, p. 243.

12) Mochida, I., Ando, T., Maeda, K., Takeshita, K., Carbon, 14, 123 (1976).

13) Mochida, I., Amamoto, K., Takeshita, K., Fuel, 57, 225 (1978).

14) Marsh, H., Walker, P. L.Jr., "Chemistry and Physics of Carbon', ed. by Walker, P. L. Jr., Marcel Dekker, Inc., New York (1979), Vol. 15, p. 228.

15) Nesumi, Y., Oyama, T., Todo, Y., Azuma, A., Mochida, I., Korai, Y., Ing. Eng. Chem. Res., in press. 


\section{要 旨}

\section{高芳香族性ピッチを添加した低硫黄減圧残さ油と FCC デカント油の共炭化}

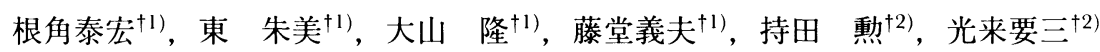

†1) 興亜石油(株)麻里布製油所, 740 山口県玖珂郡和木町和木 6-1-1

†2) 九州大学機能物質研究所, 816 福岡県春日市春日公園 6-1

低硫黄減压残油（LSVR）とFCC-デカントオイル (FCC-DO) とをチューブボムを用いて共炭化すると, 低熱膨 張係数 (CTE) の良好なニードルコークス塊が調製できるが, 底部に微小モザイク組織のコークスの薄い層が形成される。本 研究ではこの底部微小モザイクコークスを高芳香族性の A-240 ピッチを配合することによって消去することを試み た。

Figs. 1, 2 抢よび Table 2 に示すように炭化温度 460, ま たは $480^{\circ} \mathrm{C}$ ，炭化圧力 $8 \mathrm{~kg} / \mathrm{cm}^{2}$ において A-240ピッチを配合 することによって底部モザイクを減少でき，各 $5,30 \%$ の添 加により完全に消去できた。生成するコークスの上部はほぼ全 域，フロードメイン組織を示すが，A-240を添加しない LSVR/FGG-DO 共炭化生成物の上部コークスと比較して,や や大きな熱膨張係数（CTE）を示した。最適な共炭化条件の
選択により，A-240を配合して，良好な CTE と底部モザイク 組織の生成抑制とを同時に達成できると思われる。

炭化途中の顕微鏡観察, 中間生成物の溶解度ならびに構造解 析（Figs. 3〜6) により LSVR/FCC-DO 系では, LSVR の最 重質分から炭化初期に生成する QI がパラフィンを相当量含む マトリックスに溶解せず，そのため成長・合体しないで沈降 し，底部モザイクを形成するのに対して，高芳香族性の A240 を添加すると, 炭化初期に高芳香族性で, 溶解力に優れた HI-BS が相当量存在し, QI の液相での成長, 合体, 共炭化を 許容して，底部モザイクの形成を抑制すると推定できた。

さらに炭化原料の組成により炭化最適条件が変化することを 確認し，また芳香族性の高い FCC-DO の選択により， LSVR の共炭化において底部モザイクの生成を㧕制し CTE の小さい 優れたニードルコークスが製造できる可能性を指摘した。

\section{Keywords}

Carbonization, Tube bomb, Needle coke, LSVR, FCC decant oil 